\title{
1204 テジタル画像相関法による高分子材料の体積変化測定 \\ Measurement of volume change in polymers using a digital image correlation method
}

\section{○学 築山 喜久雄 (山形大学・院) . 正 黒田 充紀 (山形大学) 正 村澤 剛 (山形大学) Kikuo TSUKIYAMA \\ Mitsutoshi KURODA \\ Go MURASAWA}

Department of Mechanical Systems Engneering, Yamagata University, Yonezawa; Yamagata

Key Words: Volumetric strain, Digital image correlation method, Polycarbonate, Polymerblend.

\section{1. 背景}

近年, 高分子材料の数值モデル化に関する研究が盛ん におこなわれており，ミクロ，マクロ，あるいはメゾの 領域などの多方面からのアプローチがなされている。対 象材料に関してもゴム粒子等の混合物を含んだポリマー ブレンドからそれらを含まない単相のポリマー材まで幅 が広く種類も多い. 特にポリマーブレンド材料のモデル 化に関しては, 材料内部に存在しているゴム粒子が変形 と共に剥離することによって生じるボイドとその近傍の 力学的挙動に関する研究が多:く行われている.

本研究ではマクロスコピックな視点から混合ゴム粒子 の挙動を調べることを試みる。本報ではポリマーブレン ド解析のための重要な情報となる材料の体積変化につい て調查をおこなうことを目的とする。従来塑性変形中に 体積が保存されると考えられている非晶質材料 Polycarbonate (PC) と PC に SEBS（スチレン-エチレン-ブチ レンースチレン) ゴム粒子を混合したポリマーブレンド材 料について体積変化の測定を試みる。体積の計算にはデ ジタル画像相関法1).2) (Digital image correlation method, 以後 DIC 法と呼ぶ)を用いる。 この方法では試験片表面 内の変位勾配分布が広領域によって求められるので, 従 来の局部における寸法測定に対して沉用性があり, 様々 な応用が期待されている.

\section{2. テジタル画像相関(DIC)法}

この方法では変形前後の画像を比較することで, 各 物質点の変位量を求めることができる: その方法を以 下に示す。

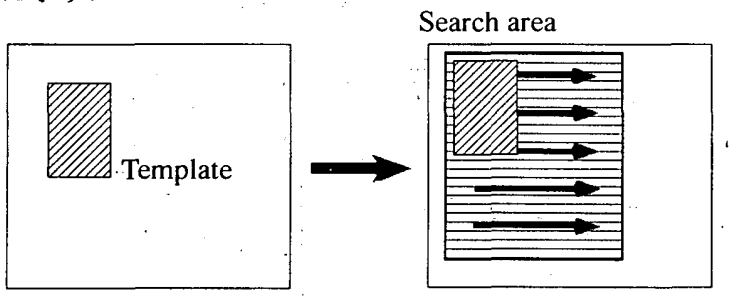

Image for undeformed material

Image for deformed material

Fig.1. Coarse searching of corresponding point.

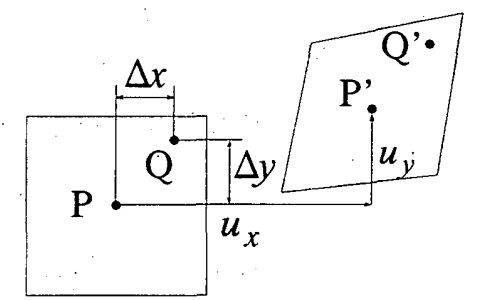

Undeformed subset Deformed subset

Fig. 2. Subsets before and after deformation.

(1) 粗探索

変形前後の変位を求めるには第一段階として, Fig. 1 の ように変形前の材料の画像に設けたテンプレート画像を
変形後の画像に重ねあわせ, テンプレ゙ート画像よりも少 し大きいサイズの領域内(Search area)で走査し, テンプレ 一下画像之輝度值分布がよく似た類似領域を探索する。 走查は 1 ピクセル間隔でおこない，類似度 $S$ は次式で定 義する.

$$
\begin{aligned}
S\left(x, y, u_{x}, u_{y}, \frac{\partial u_{x}}{\partial x}, \frac{\partial u_{x}}{\partial y}, \frac{\partial u_{y}}{\partial x}, \frac{\partial u_{y}}{\partial y}\right) & \\
= & 1.0-\frac{\sum\left[I_{u}(x, y) I_{d}(x, y)\right]}{\sqrt{\sum\left(I_{u}(x, y)^{2}\right) \sum\left(I_{d}\left(x^{*}, y^{*}\right)^{2}\right)}}
\end{aligned}
$$

ここに右辺第 2 項は相互相関保数, $x, y$ は座標値. $u_{x}$, $u_{y}$ は各方向の変位, $I_{u}(x, y)$ は変形前の座標 $(x, y)$ におけ る輝度值, $I_{d}\left(x^{*}, y^{*}\right)$ は变形後の座標 $\left(x^{*}, y^{*}\right)$ における輝 度值である。”

(2)サブピクセル探索

第 2 段階として，(1)で探索した変形前のテンプレート 画像に類似している変形後の類似領域画像(subset)内の輝 度值の分布を双一次曲線で補間する.そして Fig. 2の様に， 変形後の補間した画像と変形前のテンプレート画像の輝 度値から, 式(1)の $S$ を最小にする画像領域を再度探索し, 式(1)の方程式を解けば subset の中心 Pの変形後の座標值 $\mathrm{P}^{\prime}(x, y)$, 点 $\mathrm{P}$ の変位 $u_{x}, u_{y}$, および変位勾配 $\partial u_{x} / \partial x$, $\partial u_{x} / \partial y, \partial u_{y} / \partial x, \partial u_{y} / \partial y$ が求められ, 変形後の任意の点 の座標値 $\mathrm{Q}^{\prime}\left(x^{*}, y^{*}\right)$ が次式から求められる.

$$
\begin{aligned}
& x^{*}=x+u_{x}+\frac{\partial u_{x}}{\partial x} \Delta x+\frac{\partial u_{x}}{\partial y} \Delta y \\
& y^{*}=y+u_{y}+\frac{\partial u_{y}}{\partial x} \Delta x+\frac{\partial u_{y}}{\partial y} \Delta y
\end{aligned}
$$

これより, 任意点の変位 $u_{x}^{*}, u_{y}^{*}$ を求めることができる.

\section{3. 測定方法}

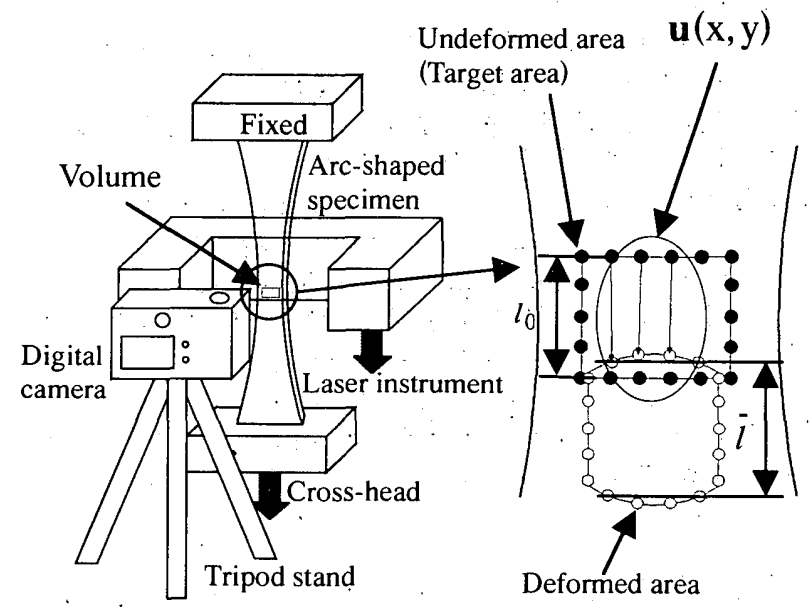

Fig. 3. Configuration of experimental Fig. 4. Unreformed and equipment. deformed area.

\footnotetext{
[№.04-40] 日本機械学会第 17 回計算力学講演会講演論文集〔2004-11.18～20・仙台市 $]$
} 
装置配置図を Fig. 3 に示す，体積変化の測定には試験 片内の一部の微小体積要素(Volume)に着目し,この Volume の変化の測定をおこなう。板厚の測定にはレーザー外径 測定器(KEYENCE;LS-3030)を用い, Volume の側面積(Target area)の測定に 2 で述べた DIC 法を用いる. くびれが生じ る部分を予め特定できるよう Fig. 3 に示すような中心の 板幅が小さい湾曲形の試験片を用いる．類似画像の認識 を容易にさせるため，白い下地にランダムな黒い斑点を カラースプレー塗料により付着させた.

塑性変形に対する体積変化を測定するため，試験片に 負荷除荷を繰り返し, 除荷時の画像データを取得する. このとき, 画像相関をおこなう際にエラーを起こさない ようにひずみ増分の大きさに注意する必要がある．画像 はデジタルカメラで収録する. Target area の変化の計算は, 微小変形前後の画像相関により Target area 付近の全ての 点の変位を求める. そして, Fig. 4 に示すように Target area を構成する各点の変形前の座標值に求めた変位を足し合 わせば，変形後の座標値が求められる。この変形後の座 標值から側面積を求め, 板厚は Target area 内で一定であ ると仮定し，体積ひずみを次式で求める.

$$
\begin{aligned}
& \varepsilon_{\mathrm{Vn}}=\left(V-V_{0}\right) / V_{0} \\
& \varepsilon_{\mathrm{Vt}}=\ln \left(V / V_{0}\right)
\end{aligned}
$$

ここに $\varepsilon_{\mathrm{Vn}}$ は公称体積ひずみ， $\varepsilon_{\mathrm{Vt}}$ は対数体積ひずみ， $V$ は変形中の.volume の体積， $V_{0}$ は初期の体積である。ま た,ひずみの算出には次式を用いる.

$$
\begin{aligned}
& \bar{\varepsilon}_{\mathrm{n}}=\left(\bar{l}-l_{0}\right) / l_{0} \\
& \bar{\varepsilon}_{\mathrm{t}}=\ln \left(\bar{l} / l_{0}\right)
\end{aligned}
$$

ここに， $l_{0}$ は Target area の縦方向の初期標点距離, 4 に示すように変形中の Target are の平均標点距離, $\bar{\varepsilon}_{\mathrm{n}}$ は 平均公称伸びひずみ， $\bar{\varepsilon}_{\mathrm{t}}$ は平均対数伸びひずみである.

\section{4. 実験秸果}

PC 及び PC に SEBS ゴム粒子を初期体積分率 20\%含有 させた PC-20vol\%SEBS の体積ひずみ-伸びひずみ関係を Fig. 5(a),(b)に示す. また, 同じく Cross-head の負荷時の 停止位置と除荷時の位置の関係をそれぞれ Fig. 6(a),(b)に, Target area の刻々の変化をそれぞれ Fig. 7(a),(b)示す. Fig. 7 内の実線は初期状態における Target area を示す.

Fig. 5(a)において，ひずみ值 0.1 よりその時の体積值を 初期値として体積ひずみの算出を開始している.これは 高分子材料特有の初期の軟化現象に起因する局所くびれ の発生により，ここまでの体積測定が不安定になったた めである.

Fig. 6(a)の図中の A は局所くびれが発生した点であるが, Cross-head の微小移動量に対して除荷時の前のステップに 対する変位増分量が大きくなっている.これにより画像 相関を行う際に，局所くびれが発生する以前の画像の輝 度値分布に比べ, 発生後の画像の輝度值分布が大きく変 化するため, 2 で述べた類似画像領域を検出することが困 難となった. そのため, Target are の軌跡は Fig. 7 図中の B のように局所くびれの発生と同時にいびつな変形に移 つてしまい，局所くびれが発生する付近において体積値 が不明確となる．そこで今回, 測定が困難であった局所 くびれ発生以前のデータの検討は行わず，その後の形状 を改めて初期状態とし局所くびれ以降の体積変化測定の 結果を示した.

\section{5. 考察}

従来塑性変形中に体積が保存されると考えられていた 非晶質材料である PCに体積增加の傾向が確認できた. Fig. 5(a)に同じ非晶質材料である PET の体積ひずみの測定例 ${ }^{3)}$ を重ねて示した。（但し，体積測定時に除荷はしていな
い)この PET の体積変形挙動は今回の PC のそれに極め て近い. しかし, 文献 1)による Boyce らの変形継続中の 体積ひずみを測定した PC の報告と比較すると, これと大 きな差がある.この差の理由については今のところ不明 である.PC-20vol\%SEBS については PC のような局所変 形を起こさないため, 全ての点で安定した測定が可能で あった．また，PC に比べて体積ひずみの大きな増加が確 認できる. 塑性変形に従い, 内部の SEBS ゴム粒子が母 材の PC から剥離してボイドが形成することが多数の実験 で確かめられている.このボイドが変形と共に成長する ため PC よりも体積ひずみが大きくなったと考えられる. そのため, PC-20vol\%SEBS の塑性領域は，PC では確認で きない白濁が目視で観察される.今後は測定方法につい てさらに検討し, データの信頼性を高める必要がある.

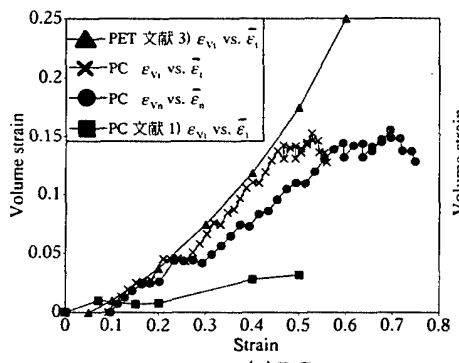

(a) PC

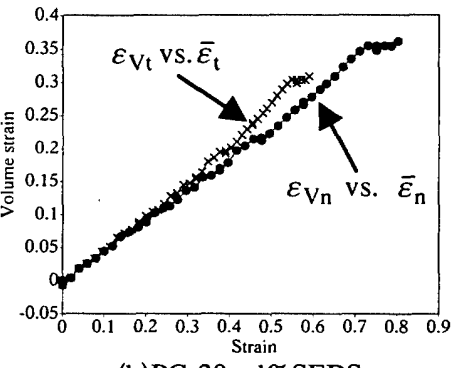

(b)PC-20vol\%SEBS
Fig. 5. Volume strain.

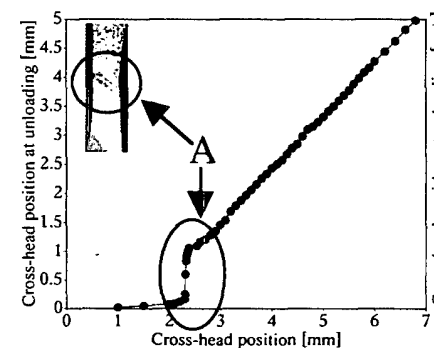

(a) PC

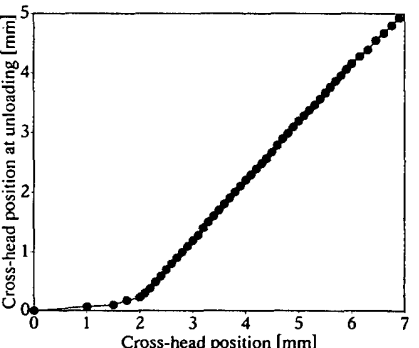

(b)PC-20vol\%SEBS
Fig. 6. Relationships between the stop position of cross-head and the position at unloading.

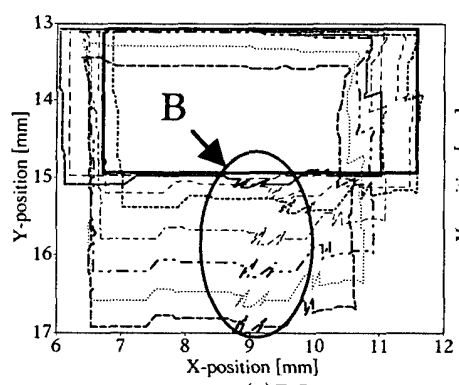

(a) PC

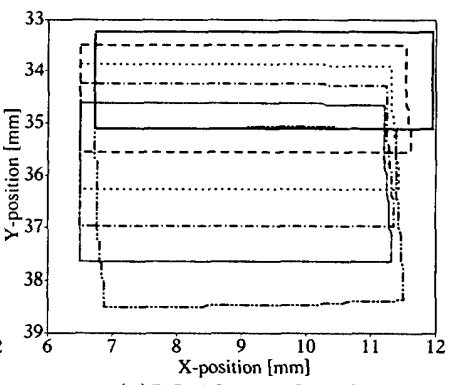

(b) PC-20vol\%SEBS
Fig. 7. Deformation of target area.

謝辞 画像相関法プログラムの使用を許可して頂いた大阪 府立大学 米山聡講師に御礼申し上げます。

\section{考文献}

1) M. C. Boyce, E. Parsons, D. M. Parks : polymer.45(2004), 2665-2684.

2) 村澤剛, 米山聡ら : 材料, 53 巻 9 号 (2004), 999-1005.

3) G'Sell, J. M. Hiver, A. Dahoun : Int. J. Solids and Struct.,39(2002), 3857-3872 